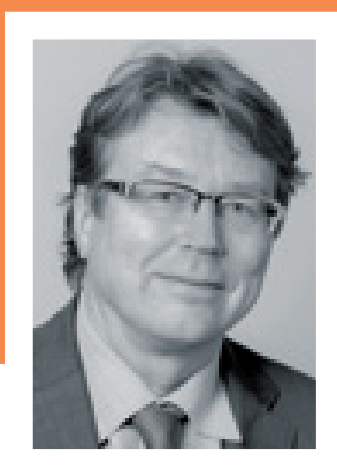

\title{
PÄÄKIRJOITUS
}

\section{UUSI ITSEOHJAUTUVA IHMINEN}

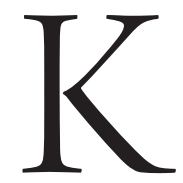

ANSALAISEN, TYÖNTEKIJÄN JA YKSILÖN ymmärryksen, taitojen, asenteiden ja käyttäytymisen muokkaaminen on kokenut muodonmuutoksen 1900-luvun alusta nykypäivään. Sisältöjen ohella niin toimijat kuin keinotkin ovat muuttuneet. Aikanaan oppivelvollisuuden sääämisen taustalla oli vakava huoli siitä, että ilman valtiovallan määrittämää julkista koulimista kansalaiset olisivat kyvyttömiä osallistumaan demokratian toimintaan. Ilman sopivaa muokkausta he saattaisivat ajatella ja toimia toisin kuin tuolloiset vallanpitäjät halusivat.

Viime vuosisadan alkupuolella kasvavia sukupolvia ojennettiin oikeisiin ajattelutapoihin ja käyttäytymismalleihin - alamaisiksi - kurilla, pakolla ja rangaistusten uhalla. Kaikki väestöryhmät oli saatava identifioitumaan kansallisvaltio Suomen jäseniksi ja omaksumaan sen edellyttämät uskomukset. Maatalouden tehostumisen ja tavaratuotannon teollistumisen vuoksi koulutus sai luottamustehtävän kasvattaa uudet sukupolvet laajenevaan palkkatyöläisyyteen sen edellyttämine moraaleineen ja taitoineen.

2000-luvulla erityisesti työmarkkinakansalaisen ominaisuuksien muokkaamiseen kohdistuvat intressit ovat voimistuneet. Tuotantotapojen ja työprosessin muutosten vuoksi työntekijöitä ei ole enää mah- dollista valvoa samaan tapaa kuin ennen tehdassaleissa. Yhä isompi osa työstä tehdään ihmisen pään sisällä. Siksi työn tekemisen kontrollikin on siirtynyt paljolti pään sisään, ajattelutapoihin ja asenteisiin.

TALOUSKASVU JA TUOTTAVUUS eivät ole vain makrotaloudellisia tavoitteita. Niillä on vastineensa organisaatioiden ja yksilöiden toiminnassa. Parin viime vuosikymmenen aikana talouspuhe on suorastaan vyörynyt ihmisten jokapäiväiseen elämään ja arkitajuntaan. Se on vallannut ison tilan julkisesta puheavaruudesta. Markkinoiden logiikkaa, talouskasvun välttämättömyyttä ja tuotannon tehostamista on koetettu juurruttaa kansalaisten ymmärrykseen ennennäkemättömällä intensiteetillä. Yksilön on ollut tärkeä oppia paikantamaan oma roolinsa tässä yhtälössä. Olemme oppineet esimerkiksi, että hallituksen tehtävä ei ole taata työllisyyttä vaan tehdä kaikkensa talouskasvun käynnistämiseksi. Käytännössä se tarkoittaa, että kansalaiset ovat yksilöinä ja työntekijöinä itse vastuussa omasta menestymisestään. Ajatukseen kuuluu, että työntekijöinä meidän kaikkien on tehtävä työmme entistä paremmin ja tehokkaammin. Mikäli aiomme menestyä tai edes säilyttää entisen elintasomme, työtä on tehtävä aiempaa enemmän ja innostuneesti. 


\title{
MEITÄ OPASTETAAN
}

\section{JOHTAMAAN OMAA YRITYSTÄMME,}

\author{
OY MIN ̈̈ AB:T̈̈.
}

Kiinnostus kansalaisen ominaisuuksiin ja niiden jalostamiseen oli vielä joitakin vuosikymmeniä sitten ennen muuta valtiolla. Nyttemmin uusliberalistisiin talousoppeihin poliittisen agendansa perustavat ylikansalliset organisaatiot, kuten Euroopan unioni ja taloudellisen yhteistyön ja kehityksen järjestö OECD, ovat nousseet tärkeiksi koulutus- ja talouspolitiikan vaikuttajiksi. Ne ovat kansallisvaltioita tärkeämpiä toimijoita uusien osaamis- ja asennevaatimusten levittämisessä arviointien, julkilausumien ja suositusten välityksellä. Esimerkiksi EU on laatinut elinikäisen oppimisen toteuttamiseksi asiakirjan uuden eurooppalaisen kansalaisen avaintaidoista, joita hallitusten olisi eri maissa ryhdyttävä istuttamaan kansalaisiinsa. Avaintaidoissa erotetaan taidollinen, tiedollinen ja asenteellinen ulottuvuus. Vaatimukset uudenlaisesta asennoitumisesta omaan menestykseen, vastuuseen, sopeutuvuuteen, yritteliäisyyteen ja vaikkapa periksiantamattomuuteen käyvät entistä syvemmälle yksilön psyykeen. Huoli niiden toteutumisesta vaatii yksilöltä enemmän tai vähemmän tietoista psyykkistä työskentelyä.

UUSIIN VAATIMUKSIIN SOPEUTUVA kansalainen onkin mitä otollisinta maaperää minätekniikoita markkinoiville positiivisuuskonsulteille. Uuden talouden vaatimusten synnyttämä "ajan henki" on luonut yksilölliseen menestykseen valmentaville konsulteille, itsen muokkaamiseen opastaville ohjelmille ja oma-apu kirjallisuudelle tuottoisat markkinat. Työntekijöiden työelämässä selviytymistä tukevat opas- kirjat ovat alati laajeneva osa self-help -kirjallisuutta.

Koululaitos ei toimi enää yksin menestyksestään vastuullisen kansalaisen kasvattajana. Se on saanut tuekseen monenkirjavan joukon ei-julkisia toimijoita. Tämä on merkinnyt myös vallankäytön muuttumista. Yksilöä muokkaava valta hakee kohdettaan verkostoissa ja epävirallisten kanavien välityksellä. Bisneshakuisen yksilön rakentamisesta on itsestään tullut bisnestä. Meitä opastetaan johtamaan omaa yritystämme, Oy Minä Ab:tä. Yksilökohtaisen menestyksen tavoittelun tulisi olla $\mathrm{Oy}$ Minä $\mathrm{Ab}: \mathrm{n}$ prioriteetti.

Myös palkansaaja on oma yrityksensä, joka tosin toimii ympäristössä, jossa menestymistä sääntelee suhde esimieheen. Jotkut konsultit ovat löytäneet tästä asetelmasta itselleen leipäpuun ja alkaneet julistaa alaistaitojen tärkeyttä. Alaistaitojen ideologiaa myydään erityisesti yritysjohdolle, mutta viime kädessä alaistaitojen on löydettävä tiensä työntekijän psyykeen.

Filosofi Slavoj Žižek (ks. Antti Saaren artikkeli) väittää ideologian toimivan optimaalisesti juuri silloin, kun subjekti kieltää ideologian ohjaavan häntä, ja kun hän sen sijaan pitää itseään autenttisena ja uniikkina yksilönä. Vastaavasti yksilö oppii varmimmin häneltä vaaditut tiedot, taidot ja asenteet silloin, kun se tapahtuu subjektin omasta halusta toteuttaa itseään ja syvimpiä toiveitaan. Lopulta uusi itseohjautuva ihminen ohjaa itseään vain niissä rajoissa, jotka on asetettu hänen ulkopuoleltaan.

Tee työtäs laulellen! Ja ilo pintaan vaik syvän märkänis!

Heikki Silvennoinen 